\title{
Cytomorphological Studies in Natural Populations of Eclipta alba (L.) Hassk. I
}

\author{
R.N. Trivedi and Kumar Rajesh \\ Cytogenetics and Population Genetics Laboratory, \\ Department of Botany, Magadh University, \\ Bodh-Gaya - 824234, India
}

Received September 26, 1983

Eclipta alba (L.) Hassk. belongs to a large and highly natural family Compositae. This is the only species which occurs in India (Hooker 1882) and described as a variable species by systematists. This commonly grows as a weed on the roadside, wasteland, drains, orchards, gardens and grazing fields. It is an annual herb and its several forms exist in nature which differ strikingly in many morphological features either growing in populations or colonizing at new places. Some of the variable forms have even the merit of taxonomic recognition.

The study of natural population has become now a days a major preoccupation of systematists and cytogeneticists. The community of potentially interbreeding individuals at a given locality is termed as local population by population geneticists. All members of a local population share in a single gene pool and termed as a group of individuals so situated that any one of them have equal probability of mating with each other and producing offsprings (Mayr 1970). An actual local population will always deviate more or less from the stated ideal (Baker 1965, Trivedi and Trivedi 1982). A species in time and space is composed of numerous such local populations, each one intercommunicating and intergrading with the others which may be visualised in this species from different localities. The present investigation primarily concerns the recognition of such population and to study them cytogenetically. This paper includes a part of investigations being carried out in this species and contains mitotic and meiotic studies in two natural populations of E. alba, details of which are given in materials and methods.

\section{Materials and method}

Materials used for the present investigation is Eclipta alba from two localities of Gaya District in the State of Bihar as shown in Table 1. The herbaria were identified from Botanical Survey of India, Shibpur, Calcutta. The voucher specimens have been deposited in the Department of Botany, Magadh University, BodhGaya herbaria.

For somatic chromosome studies, young and healthy root tips were pretreated with alpha-bromo-napthalene for 1.5 hours to 2 hours and fixed in $1: 3$ acetoalcohol between 10.15 A.M. to 11.00 A.M. The root tips were stained in acetocarmine and

1 Department of Botany, Gaya College, Gaya -823002 , India. 


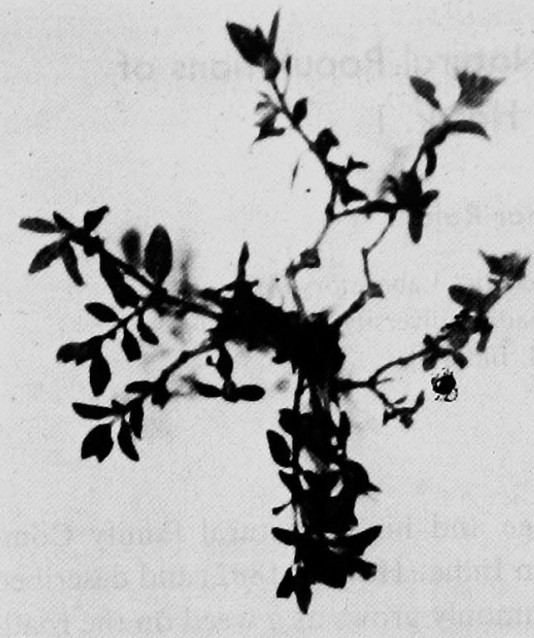

1
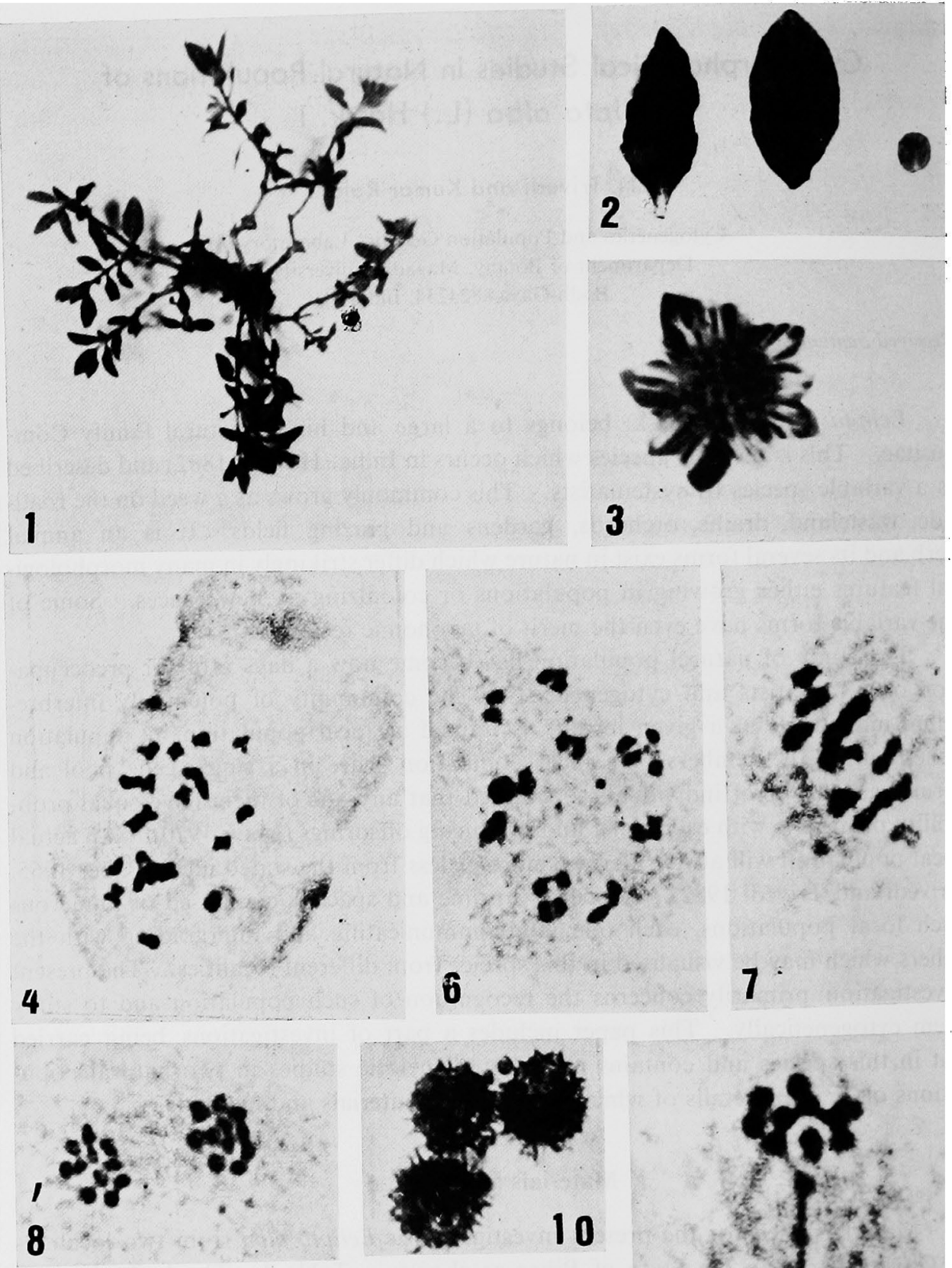

3

4

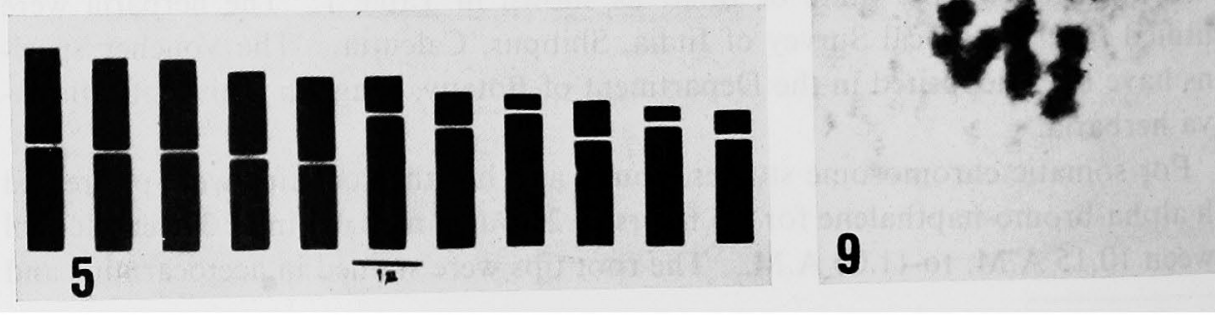


squashed in $45 \%$ acetic acid. The detailed structure of chromosome was made out from enlarged photographs of temporary preparations. The total form percentage (T.F. \%) has been calculated as

$$
\frac{\text { Sum total of short arm lengths }}{\text { Total length of chromosomes }} \times 100
$$

given by Huziwara (1962).

Floral buds of proper size were fixed in the same way as described for root tips and the anthers were squashed in acetocarmine directly. The method of fixation and staining and fixative and stain, used were the same as for somatic studies.

Table 1. Period of collection and localities of two populations of Eclipta abla

\begin{tabular}{lll}
\hline \hline Populations & \multicolumn{1}{c}{ Locality } & Period of collection \\
\hline 1. Ea0776 & $\begin{array}{l}\text { Magadh University } \\
\text { Campus, Bodh-Gaya }\end{array}$ & 10 th July, 1976 \\
2. Eal476 & $\begin{array}{l}\text { Foot hills of } \\
\text { Brahmyoni hills, Gaya }\end{array}$ & 15 th July, 1976 \\
\hline
\end{tabular}

\section{Observations}

1. Locality: M. U. Campus, Bodh-Gaya

Magadh University Campus, which is $3 \mathrm{Kms}$ from Bodh-Gaya and $16 \mathrm{Kms}$ from main Gaya town, is spreading over in an area of more than 300 acres. The campus has started growing some twelve years back and still in the process of development.

A vast part of the area is partly under cultivation and partly an open grazing field. Eclipta alba growing under this condition proves to be a good example of a weed growing in an open and disturbed habitat.

\section{Population: Ea0776}

The plant of this locality constitutes a large population of prostrate habit with smaller rounded or lanceolate leaves, entire margin and hairs sparsely dispersed over stem and leaf surfaces (Figs. 1,2 and 3). This constituted a large population consisting of about thousand of plants.

A somatic chromosome count of $2 n=22$ (Fig. 4) was made from root tip cells of the plant. The size of the chromosomes varied from $1.875 \mu \mathrm{m}$ to $2.80 \mu \mathrm{m}$ in length. The karyotypic analysis showed that five pairs of chromosomes were of median type, four pairs were of sub-median type and two pairs were of sub-terminal

Figs. 1-10. 1, plant of prostrate habit of Eclipta alba. 2, leaves of prostrate plant. 3, flower of prostrate plant. 4 , mitotic chromosomes at metaphase showing twenty two chromosomes. 5, idiogram of mitotic chromosomes. 6, PMC at diakinesis showing eleven clear bivalents with darkly stained nucleolus. 7, PMC at metaphase I showing six clear bivalents and rest forming multivalents. 8, PMC at anaphase I showing $11: 11$ chromosomes at the two poles. 9, PMC at anaphase I showing chromosomal bridge. 10, fertile pollen grains. 
type. The chromosome pairs are represented in idiogram (Fig. 5). No secondary constrictions were observed in any of the dividing cells. The mitosis in all its phases, has been found to be quite regular. The detailed karyotypic measurements are summarised in Table 2.

Meiotic division in the material was found to be highly non-synchronized. The gametic chromosome number $n=11$ were seen both at diakinesis and metaphase $I$. At diakinesis, one or two chromosomes were seen to be associated with darkly stained neucleolus (Fig. 6). At this stage, some univalent and clumped multivalents were also recorded. Multivalents were also observed at metaphase $I$ in few pollen mother

Table 2. Chromosomes of two localities of the species Eclipta alba

\begin{tabular}{cccccr}
\hline $\begin{array}{c}\text { Popula- } \\
\text { tions }\end{array}$ & $2 \mathrm{n}$ & $\begin{array}{c}\text { Range of } \\
\text { chromosome } \\
\text { length in } \mu \mathrm{m}\end{array}$ & $\begin{array}{c}\text { Total } \\
\text { chromosome } \\
\text { length in } \mu \mathrm{m}\end{array}$ & $\begin{array}{c}\text { Number of } \\
\text { chromosome } \\
\text { pair }\end{array}$ & T.F.\% \\
\hline Ea0776 & 22 & 1.875 to 2.80 & 52.05 & $5 \mathrm{M}$ & \\
& & & & $4 \mathrm{Sm}$ & 33.42 \\
Eal476 & 22 & 2.40 to 3.94 & 69.76 & $2 \mathrm{St}$ & \\
& & & & $5 \mathrm{M}$ & 37.4 \\
& & & $2 \mathrm{Sm}$ & \\
\hline
\end{tabular}

M: Median; Sm: Sub-median; St: Sub-terminal

Table 3. Nature and frequency of chromosome association in two populations of E. alba at metaphase I

\begin{tabular}{lcccccccc}
\hline \multirow{2}{*}{$\begin{array}{c}\text { Popula- } \\
\text { tions }\end{array}$} & $\begin{array}{c}\text { Frequency } \\
\text { of PMCs }\end{array}$ & I & II & III & IV & V & VI \\
\cline { 4 - 8 } & 30 & 0 & 11 & 0 & 0 & 0 & 0 \\
Ea0776 & 12 & 6 & 8 & 0 & 0 & 0 & 0 \\
& 4 & 2 & 6 & 0 & 2 & 0 & 0 \\
& 4 & 0 & 8 & 0 & 0 & 0 & 1 \\
\hline & 30 & 0 & 11 & 0 & 0 & 0 & 0 \\
Eal476 & 10 & 2 & 4 & 0 & 3 & 0 & 0 \\
& 8 & 4 & 7 & 0 & 1 & 0 & 0 \\
& 2 & 1 & 9 & 1 & 0 & 0 & 0 \\
\hline
\end{tabular}

cells (Fig. 7) but quadrivalents were of more common occurrence. The nature and frequency of chromosome association in different PMCs have been summarized in Table 3. The details of chiasma frequency and analysis of ring and rod bivalents are given in Table 4.

Anaphase I was also found to be quite regular (Fig. 8), however, the chromosomal disjunction at more than two poles, laggards and chromosomal bridges (Fig. 9) were also seen in few PMCs. At tetrad stage 1.9 per cent of PMCs had been seen with micronuclei besides fertile pollen grains (Fig. 10). The percentage of pollen sterility varied from anther to anther and was calculated to be 12.7 per cent (Table 5). 


\section{Locality: Brahmyoni Hills, Gaya}

The location of this town is geographically quite interesting in the sense that it is situated at the foot of Brahmyoni Hills which is about a furlong in the south of Gaya town. The climate of this place is also very extreme as in summer season, the mercury touches upto $48^{\circ} \mathrm{C}$ whereas in winter season it drops to $5^{\circ} \mathrm{C}$.

\section{Population: Ea1476}

This was a good sized population containing about twelve hundred plants of different ages and stages of flowering. The general habit of the plants was prostrate, with comparatively long roots, slender stems, leaves small, apex obtuse with smooth margin. Flowers were small and the plant body was covered with whitish brown hairs.

Table 4. Chromosome pairing and chiasma frequency in two populations of E. alba at metaphase I

\begin{tabular}{|c|c|c|c|c|c|c|c|c|c|}
\hline \multirow{2}{*}{$\begin{array}{l}\text { Popu- } \\
\text { lations }\end{array}$} & \multirow{2}{*}{$\begin{array}{l}\text { No. } \\
\text { of } \\
\text { PMCs } \\
\text { stu- } \\
\text { died }\end{array}$} & \multicolumn{3}{|c|}{$\begin{array}{l}\text { No. of bivalents per } \\
\text { PMC }\end{array}$} & \multirow{2}{*}{ Total } & \multirow{2}{*}{$\begin{array}{c}\begin{array}{c}\text { Chiasmata } \\
\text { per PMC }\end{array} \\
\text { Range Mean }\end{array}$} & $\begin{array}{c}\begin{array}{c}\text { Termina- } \\
\text { lised } \\
\text { chiasmata }\end{array} \\
\end{array}$ & \multirow{2}{*}{$\begin{array}{c}\text { Half } \\
\text { chia- } \\
\text { sma } \\
\text { per } \\
\text { chro- } \\
\text { moso- } \\
\text { me }\end{array}$} & \multirow{2}{*}{$\begin{array}{c}\text { Termi- } \\
\text { nali- } \\
\text { zation } \\
\text { coef- } \\
\text { fici- } \\
\text { ent }\end{array}$} \\
\hline & & $\begin{array}{c}\text { Ring } \\
\text { Range Mean }\end{array}$ & $\begin{array}{r}\mathbf{R} \\
\text { Rang }\end{array}$ & Mean & & & Range Mean & & \\
\hline Ea0776 & 50 & $9-11 \quad 10$ & $0-2$ & 1 & 11 & $20-22 \quad 21$ & $19-22 \quad 20.5$ & 0.95 & 0.97 \\
\hline Eal476 & 50 & $10-11 \quad 10.25$ & $0-1$ & 0.75 & 11 & $20-22 \quad 21.25$ & $19-22 \quad 20.5$ & 0.96 & 0.96 \\
\hline
\end{tabular}

Table 5. Pollen analysis in two populations of E. alba

\begin{tabular}{lcccccc}
\hline \hline $\begin{array}{l}\text { Popu- } \\
\text { lations }\end{array}$ & $\begin{array}{c}\text { No. of } \\
\text { pollen } \\
\text { studied }\end{array}$ & $\begin{array}{c}\text { No. of } \\
\text { normal } \\
\text { pollen }\end{array}$ & $\begin{array}{c}\text { No. of } \\
\text { sterile } \\
\text { pollen }\end{array}$ & $\begin{array}{c}\text { Percen- } \\
\text { tage of } \\
\text { sterile } \\
\text { pollen }\end{array}$ & $\begin{array}{c}\text { No. of } \\
\text { small } \\
\text { sized } \\
\text { pollen }\end{array}$ & $\begin{array}{c}\text { Percentage } \\
\text { of small } \\
\text { sized pollen }\end{array}$ \\
\hline Ea0776 & 1020 & 870 & 130 & 12.7 & 20 & 1.9 \\
Ea1476 & 1010 & 910 & 80 & 7.8 & 20 & 1.9 \\
\hline
\end{tabular}

The somatic chromosme number was found to be $2 n=22$ (Fig. 11) in almost all the root tip cells that were squashed and examined. The size of the chromosome varied from $2.40 \mu \mathrm{m}$ to $3.94 \mu \mathrm{m}$ in length. The karyotypic analysis showed that four pairs of chromosomes were of median type, five pairs of sub-median type and two pairs of sub-terminal type. The chromosome pairs are represented in the idiogram (Fig. 12). The subsequent stages of mitosis did not show any kind of irregularity. The detailed karyotypic measurements are summarized in Table-2.

The meiotic division in the material appeared to be highly non-synchronized. The gametic chromosome number $\mathrm{n}=11$ was observed in this population both at diakinesis and metaphase I stages. At diakinesis, bivalents were seen to be in three groups around the nucleolus (Fig. 13); in few PMCs multivalents generally of quadrivalents nature were also marked. At metaphase I also, few PMCs showed multivalents of different nature and frequency (Fig. 14). The nature and frequency of chromosome association at metaphase I are summarised in Table 3 . The details of chiasma frequency and number of rod and ring bivalents are summarised in Table- 4 . 
At anaphase I, equal distribution of chromosomes was observed in most of the PMCs (Fig. 15). However, the chromosomal laggards, unequal separation of chromosomes at the two poles and lagging bivalents were most common abnormalities observed at this stage (Fig. 16). At anaphase II, apart from the normal four groups

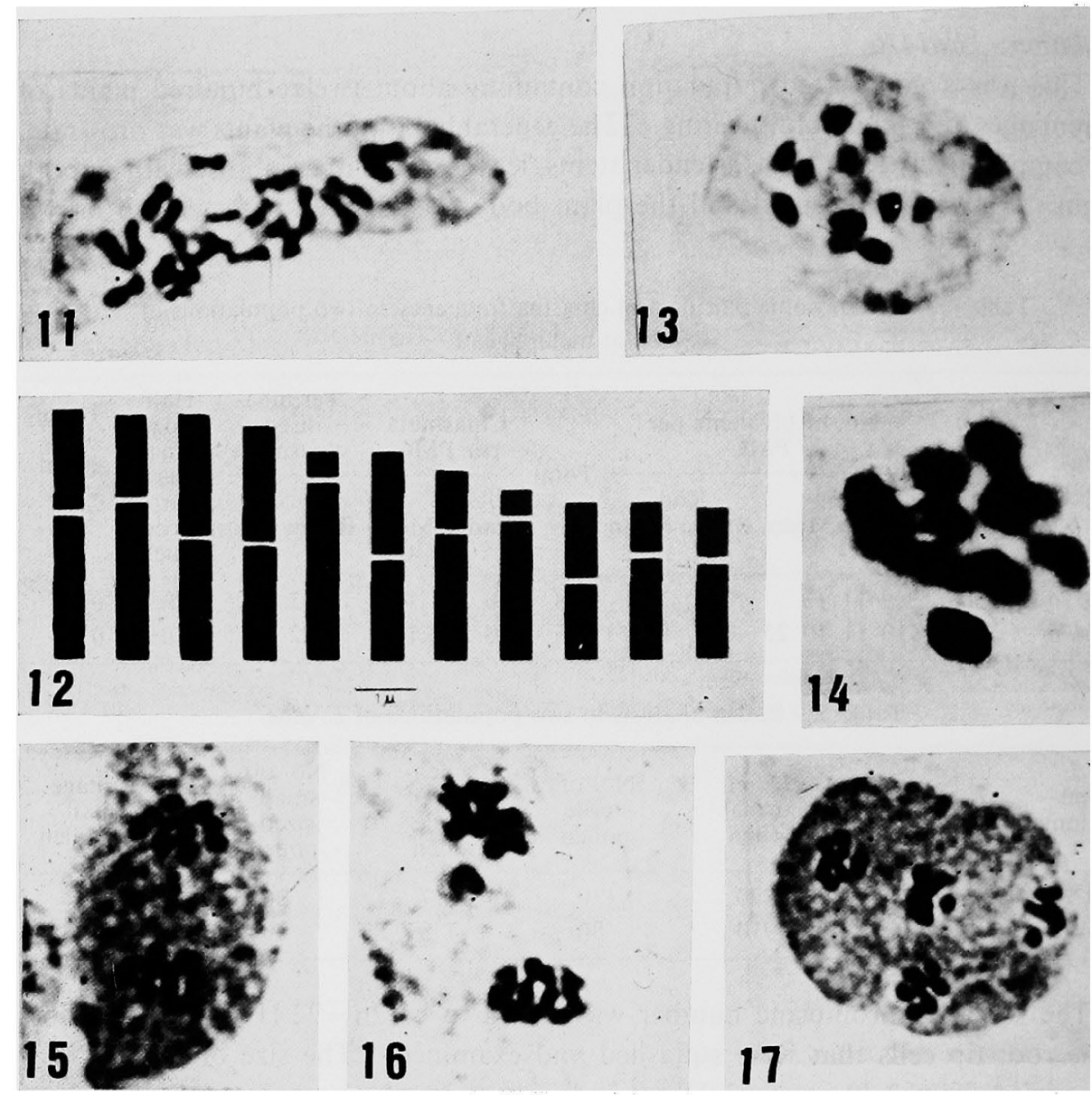

Figs. 11-17. 11, mitotic chromosomes at metaphase showing twenty two chromosomes. 12, idiogram of mitotic chromosomes. 13, PMC at diakinesis showing eleven bivalents with nucleolus. 14, PMC at metaphase I showing 4 bivalents and a chain of 3 and 4 bivalents showing interbivalent connections. 15, PMC at anaphase I showing $11: 11$ chromosomes at the two poles. 16, PMC at anaphase I showing lagging bivalents. $17, \mathrm{PMC}$ at anaphase II showing unequal distribution of chromosomes at the 4 poles.

of chromosomal complements at four poles, some irregularities like, disturbed polarity, laggards, multi-polarity and unequal separation of chromosomes were seen (Fig. 17). This, in turn, led to the formation of micronuclei at the tetrad stage. The overall pollen sterility for this population was estimated to be 7.8 per cent (Table 5). 


\section{Discussion}

The chromosomes and the detailed idiograms of the two populations in the species $E$. alba provide information of the nature of karyotypic evolution. So far as the two populations with $2 n=22$ are concerned, both of them can be grouped into one species. But, the amount of variations in the length of chromosome size and in the morphology between different pairs suggest that the specialization in the karyotype has not altogether been absent. The two populations differ in the position of the centromere, total chromosome length and T.F. $\%$. The difference occurs in the pairs of the medium size chromosomes with median centromeres and variations in the relative position of the centromeres pairs from median to slightly sub-median or from strikingly sub-median to slightly sub-terminal in some of the pairs. The karyptype of the population Eal476 is, therefore, more symmetrical than of the population Ea0776.

The haploid number of the species is eleven in both the poluations. The total chromosome length in the populations were $52.05 \mu \mathrm{m}$ and $69.75 \mu \mathrm{m}$ respectively. The chromosome length ranged from $1.875 \mu \mathrm{m}$ to $2.80 \mu \mathrm{m}$ and $2.40 \mu \mathrm{m}$ to $3.94 \mu \mathrm{m}$ respectively. Earlier workers like Mehra et al. (1965), Thakur and Singh (1968) have emphasized that the basic number eleven is a derivation of ascending series from 6,8 and 9 of the tribe Heliantheae. Thus, the chromosomes may have undergone changes by variation in size and position of the centromere points which has already been discussed.

The meiotic behaviour in the two populations shows the chromosome number as eleven and there is also both regular and irregular meiosis of same kind and intensity. Looking to the detailed behaviour of the meiosis in the above populations, it is observed that the two populations have low average of rod bivalents and higher average of ring bivalents (Table 4). It is generally believed that the members of Compositae are outbreeders as they are mostly pollinated by bees. As such, they should have low chiasma frequency and low basic number as stressed by Grant (1958) and Stebbins (1971). However, in a limited area, the members of the family Compositae show a very homogeneous population almost like progeny of selfers. The type of bees found pollinating the members of Compositae work within a narrow radius (capitulum). Under these circumstances they will inevitably bring out more self pollination than cross pollination. The habit of bees to confine their attention mainly to the local patch of flower tend to restrict the pollen dispersal in the pollinated plants to a close circle of individuals (Mehra 1977). Thus, the populations belonging to this should have high chiasma frequency per nucleus. The high chiasma frequency in these two populations support this contention. Further, the range of frequency of chiasmata and half chiasma per chromosome is also the same. Thus, the tendency shown by the karyotypic study that the two populations are similar, is further reinforced by their almost identical meiotic behaviour.

The differences in the karyotype are also revealed by the recombination index, breeding system and other morphological and floral characters. This may be an outcome of the environmental influences. No wonder, therefore, that in the meiotic abnormalities, one finds the degree of anomalies, is not always the same in the 
above two populations. An individual genotype assumes particular characteristics in a given environment. In a second environment it may remain the same or it may be different. The amount by which the expression of individual characteristics of a genotype is changed by different environments, is a major of the plasticity of the characters mentioned above, which is quite revealing in these populations. Plasticity is therefore shown by a genotype when its expression is able to be altered by environmental influences.

\section{Summary}

Detailed somatic and meiotic studies in the two populations of Eclipta alba (L.) Hassk. of the family Compositae have been carried out. Collection of materials for cytogenetical studies has been made from their natural populations. In the populations Ea0776 and Ea1476, the karyotypic studies reveal that the haploid number is eleven. The two populations have different pairs of chromosome which varied in length. The karyotype of population Ea0776 is more asymmetrical. Meiotic studies in the two populations show the chromosome number as eleven and there is also both regular and irrregular meiosis. There are differences in the nature of chromosome association and chiasmata in these populations. Plasticity shown by a genotype when expressed is able to be altered by environmental influences.

\section{References}

Baker, H. G. 1965. Characteristics and Modes of Origin of Weeds. In: The Genetics of Colonizing Species. H. G. Baker and G. L. Stebbins (Eds.), New York.

Grant, V. 1958. The regulation of recombination in plants. Cold. Spr. Harb. Sym. 23: 337-363. Hooker, J. D. 1882. The Flora of British India. L. Reeve and Co. Ltd.

Huziwara, Y. 1962. Karyotype analysis in some genera of Compositae VIII. Further studies on the chromosome of Aster. Amer. J. Bot. 49: 116-119.

Mayr, E. 1970. Populations, Species and Evolution. The Belknap Press of Harvard University Press. Cambridge, Massachusetts.

Mehra, P. N., Gill, B. S., Mehra, J. K. and Sidhu, S. S. 1965. Cytological investigations on the Indian Compositae I. North India Taxa. Caryologia 18: 35-68.

- 1977. Cytological investigations on the Indian Compositae VI. Chromosomes and evolutionary phylogeny. Cytologia 42: 347-356.

Stebbins, G. L. 1971. Chromosomal Evolution in Higher Plants. Edward Arnold Ltd., London. Thakur, V. and Singh, N. P. 1968. Cytology of Edipta alba Hassk. J.I.B.S. 26: 206-210.

Trivedi, R. N. and Trivedi, M. P. 1982. Meiotic studies in the three natural populations of Lindenbergia indica. Rec. Trend. Bot. Res. Symposium 1: 3-4. 